Research Article

\title{
MEASUREMENT OF SOCIAL FUND ASSISTANCE PROGRAM AND ECONOMIC INDICATORS OF BANGKA BELITUNG ISLANDS IN THE EFFORT TO REDUCE POVERTY RATE
}

\author{
Julia $^{1}$, Khairiyansyah ${ }^{2}$ \\ ${ }^{1}$ Accountancy, Bangka Belitung University, Indonesia \\ ${ }^{2}$ Management, Bangka Belitung University, Indonesia
}

Article history:

Submission 23 October 2021

Revised 05 November 2021

Accepted 07 November 2021

*Corresponding author:

E-mail:

saputrajulia07@gmail.com

\begin{abstract}
This study aims to analyze the relationship and influence of social assistance on the number of poor people in the Province of the Bangka Belitung Islands. There are control variables as comparison, namely; unemployment, central government debt, economic growth and poverty. The research method uses a quantitative approach with nonparametric statistics, annual data (2015-2020) and elasticity are used to measure the magnitude of change in the number of poor people due to additional social assistance. Spearman Rank test to examine the relationship of each variable (the number of unemployed, central government debt and economic growth) to the amount of poverty in Indonesia. The results of the study show that there is a very strong relationship between social assistance for Contribution Assistance Recipients and the Family Hope Program on the number of poor people. A negative sign indicates that social assistance can significantly reduce poverty, with the strongest impact being the program. There is a strong relationship between debt and the number of poor people. The slowdown in economic growth has been proven to be unrelated to the number of poor people. This means that, in the midst of an economic slowdown, the number of poverty in Indonesia can be reduced through social assistance programs, job creation as laborers and government debt is allocated for productive activities and economic activities that have a direct impact on the poor and the poor. vulnerable to poverty.
\end{abstract}

Keywords: Social Assistance, Economy, Poverty, Bangka Belitung

\section{Introduction}

In an effort to reduce the poverty rate broadly, the economy can be done by keeping economic growth at a high level. Because economic growth will encourage the economy by creating the availability of jobs, so that in the end it will have an impact on increasing people's income while reducing poverty levels. However, economic growth alone will not be enough to fight poverty, if other policies are not implemented clearly and clearly to improve people's living standards and welfare

How to cite:

Julia \& Khairiyansyah (2021). Measurement of Social Fund Assistance Program and Economic Indicators of Bangka Belitung Islands in the Effort to Reduce Poverty Rate. Indonesian Journal of Social Science Research, 2(2), 97 - 103. doi: $10.11594 /$ ijssr.02.02.06 
(Tarabini, 2010). Social welfare is a condition in which all needs can be met both materially, spiritually and socially so that they can live properly and are able to develop themselves, and can carry out their social functions. This will trigger economic conditions both nationally and globally.

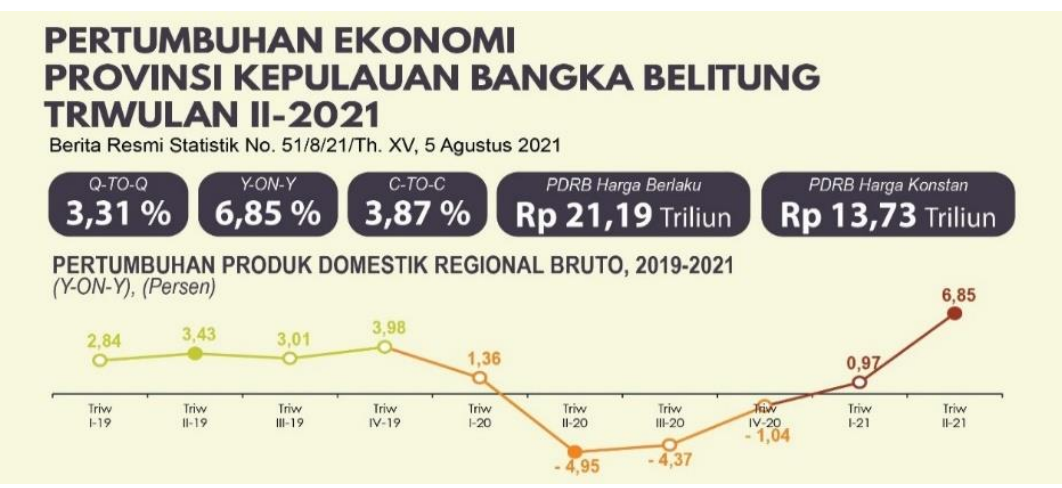

Figure 1 Bangka Belitung Province Economic Growth Source : Central Bureau of Statistics Bangka Belitung

The Indonesian Ministry of Finance revealed that the Bangka Belitung economy recorded a contraction in the second quarter $(4.95 \%)$ and in the third quarter $(4.37 \%)$ due to the impact of the Corona or COVID-19 pandemic. Therefore, the economic turmoil that occurs due to the Covid-19 pandemic will directly have an impact on Indonesia's international economic performance, both in terms of trade in goods/services and financial performance. In the end, it will have an impact on the slowdown in Indonesia's economic growth, which is reflected in changes in gross domestic income which are increasingly declining. This condition directly explains the domestic impact through the weak purchasing power of the people, especially poor households.

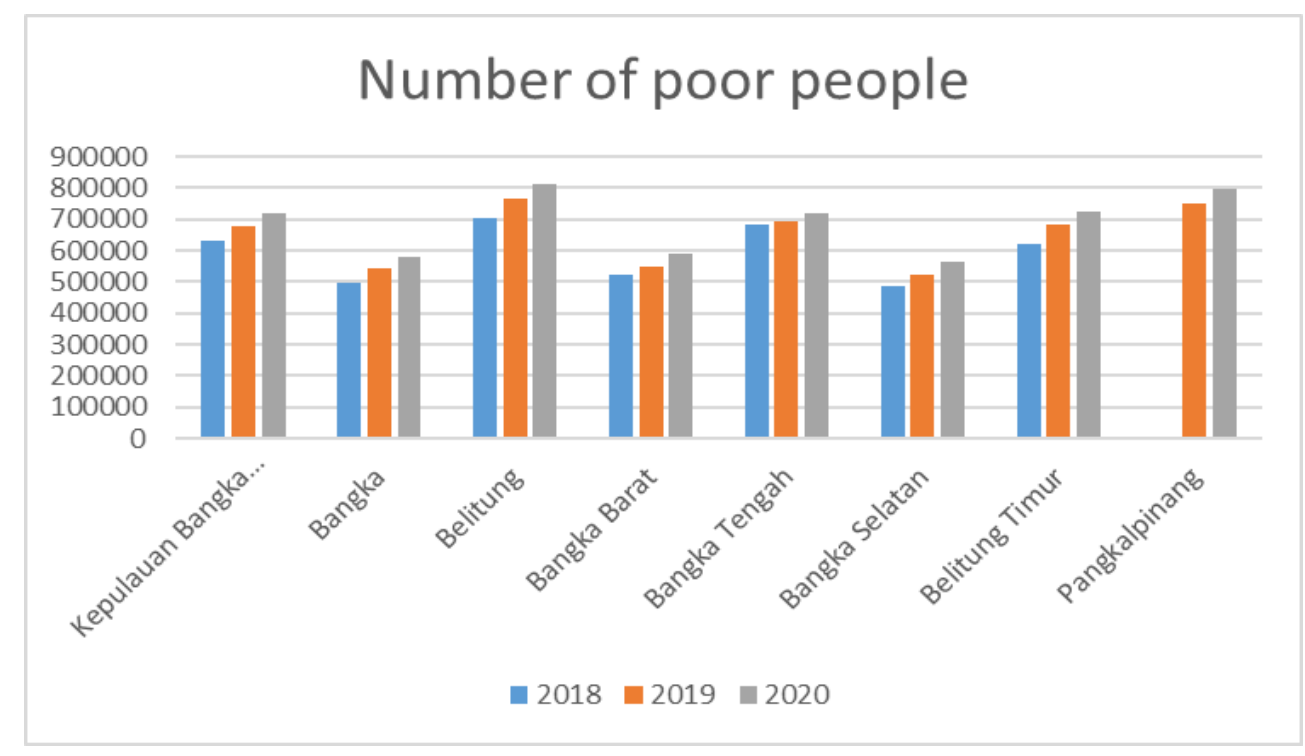

Graph 1. Number of Poor Population (Soul)

Source : Central Bureau of Statistics Bangka Belitung 
At the time of the decline in economic growth, the number of poor people in the Province of the Bangka Belitung Islands experienced an increase. Data from the Central Statistics Agency (BPS) of the Bangka Belitung Islands Province shows the number of poor people in 2020 has increased by 43739 thousand people, where previously in 2019 it was 677716 thousand people. This means that the impact of the Covid-19 pandemic has greatly affected the increase in the number of poor people in Bangka Belitung. The social assistance program in question consists of the JKN-PBI (National Health Insurance-Recipients of Subsidized Contribution Assistance) program, $\mathrm{PKH}$ (Hopeful Family Program) and Cash Social Assistance. This is considered quite successful in dealing with price fluctuations (inflation) of basic goods, especially rice (Septiadi D, 2016).

The next social assistance program, JKN$\mathrm{PBI}$, is intended as protection from the govern- ment for the health of poor families. This is considered quite important because health costs are not small and difficult to reach for poor families. So that with the guarantee of health protection, poor families can maintain their physical health from disease without having to burden the poor family's finances (Tri, 2013). $\mathrm{PKH}$ is the first and only program in Indonesia to adopt the Conditional Cash Transfer (CCT) scheme, which was previously considered successful in improving poverty problems in Latin American countries (Laura B Rawlings, 2005).

Social assistance is a form of economic resilience program for poor households in facing shocks in terms of food, health, education as well as economic crises and natural disasters. This means that social assistance is aimed not only at alleviating poverty, but also as a protection guarantee program in an effort to minimize the economic vulnerability of poor households.

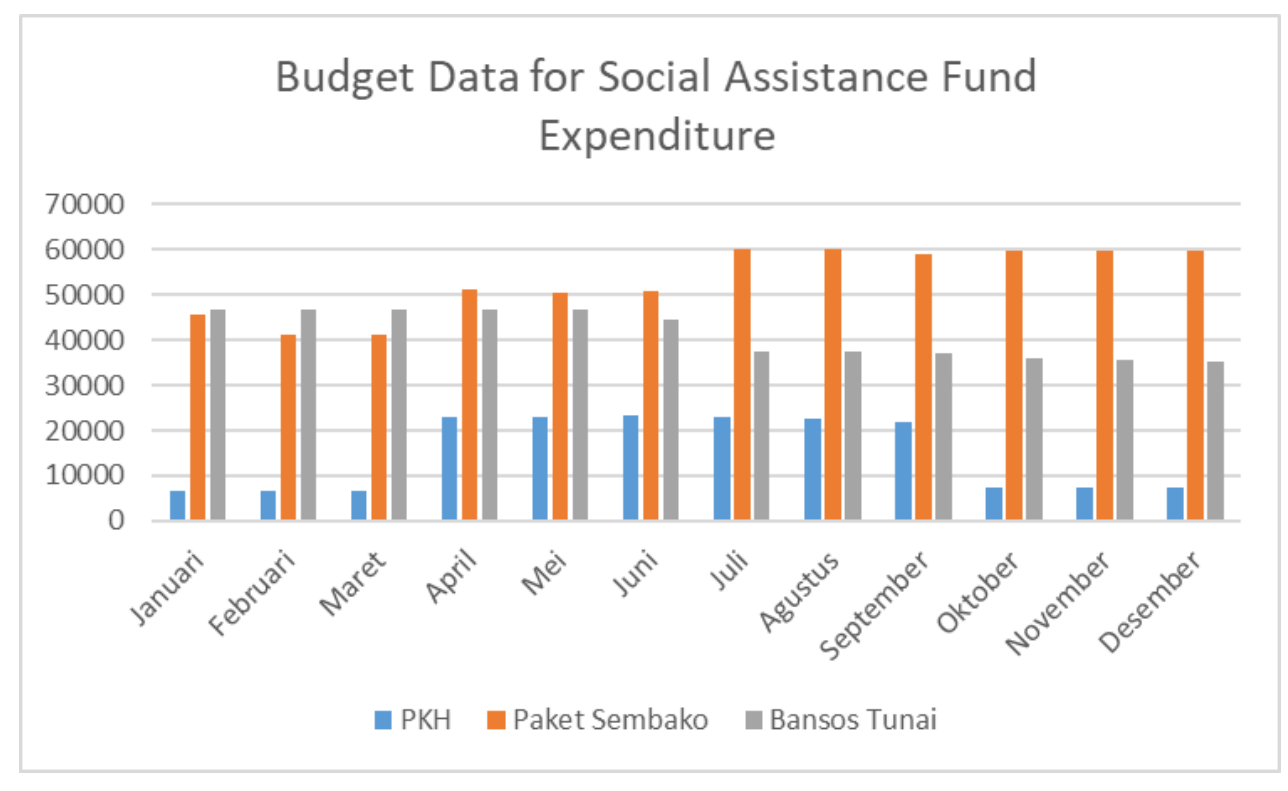

Graph 2. Budget Data for Social Assistance Fund Expenditure Years 2020

Data on social assistance budget spending from 2020 shows an upward trend. The largest social assistance budget in 2020 was dominated by the PKH, PBI and In 2020 the social assistance program will be even bigger, this is because it is to help the community in dealing with economic difficulties during the Covid-19 pandemic. As described above, Bangka Belitung's economic growth conditions have slowed, but the number of poverty has shown a decline. The existence of social assistance indicates a factor that reduces the amount of poverty in Bangka Belitung. However, in the midst of stagnating economic growth, where will the government-managed social assistance finance come from.

This study aims to analyze the relationship and influence of social assistance, economic 
growth and unemployment on the number of poor people in Indonesia. This is intended to see the effectiveness of social assistance in reducing the number of poor people compared to other government policies, namely economic growth and job creation. The benefits of this research are as an evaluation material for government policies related to effective conditions for the distribution of social assistance funds, and as scientific development, especially in the field of public policy analysis.

\section{Method}

The research method uses a quantitative approach with nonparametric statistics. The correlation test uses the Spearman Rank test using the SPSS 24 statistical tool to see the response to changes in the number of poverty due to changes in exogenous variables. The data used in this study are time series data from 2015 to 2020 . The following is the Spearman Rank test formula (Spearman, 1904):

$$
\begin{aligned}
& \text { Formula Rank Spearman : } \mathrm{r}_{\mathrm{s}}=\frac{\sum_{i=1}^{n}\left(R_{X_{i}}-\bar{R}_{X}\right)\left(R_{Y}-\bar{R}_{Y}\right)}{\sqrt{\sum_{i=1}^{n}\left(R_{X_{i}}-\bar{R}_{X}\right)^{2}} \sqrt{\sum_{i=1}^{n}\left(R_{Y}-\bar{R}_{Y}\right)^{2}}} \\
& \mathrm{r}_{\mathrm{s}} \quad=\text { Spearman rank correlation coefficient } \\
& \mathrm{n} \quad=\text { number of samples (data) } \\
& \mathrm{X}_{\mathrm{i}} \quad=\text { The i-th independent variable }(\mathrm{i}=1,2 \ldots .6),\left(\mathrm{X}_{1}(\mathrm{PBI}), \mathrm{X}_{2}(\mathrm{PKH}), \mathrm{X}_{3}(\mathrm{BST})\right. \\
& \mathrm{Y} \quad=\text { Number of Poor Population }
\end{aligned}
$$

\section{Results and Discussion}

Normality, Linearity and Heteroscedasticity Test

To determine the right type of correlation test, it is necessary to test for normality, linearity and heteroscedasticity first. If the minimum requirements for normality and heteroscedasticity are met by independent variables, then the appropriate correlation test is the Spearman-rho test. The test results are shown in Table 1.

Table 1. Normality Test

One-Sample Kolmogorov-Smirnov Test

\begin{tabular}{llr}
\hline & & \multicolumn{1}{c}{ Unstandardized Residual } \\
\hline Normal Parameters ${ }^{\mathrm{a}, \mathrm{b}}$ & & \multicolumn{1}{c}{0} \\
\cline { 2 - 3 } & \multicolumn{1}{c}{ Mean } &, 232900000 \\
\hline Most Extreme Differences & Std. Deviation &, 121 \\
\cline { 2 - 3 } & Absolute &, 132 \\
\cline { 2 - 3 } & Positive &,- 122 \\
\hline Test Statistic & Negative &, 121 \\
\hline Asymp. Sig. (2-tailed) & &, $200^{c, d}$ \\
\hline
\end{tabular}

Source: Secondary Data, 2020

Based on the spss output table above, it is known that the significance value of Asymp. Sig (2-tailed) is 0.200 which is greater than 0.05 . So according to the basis of decision making in the Kolmogorov-Smirnov normality test, it can be concluded that the data are normally distributed.

\section{Linearity Test}

The linearity test is one of the classical assumption tests that is carried out to determine the linear nature of the data distribution between the variables $\mathrm{X}$ and $\mathrm{Y}$. It is necessary to know whether the linear nature of the $X$ and $Y$ relationship affects the level of validity of the resulting regression model. 
Table 2. Linearity Test

\begin{tabular}{|c|c|c|c|c|c|}
\hline \multicolumn{6}{|c|}{ ANOVA Table } \\
\hline & & & Mean Square & $\mathrm{F}$ & Sig. \\
\hline \multirow{5}{*}{$\begin{array}{l}\text { Number of Poor Population } \\
\text { *Bangka Belitung Islands } \\
\text { Economic Growth }\end{array}$} & \multirow{3}{*}{$\begin{array}{l}\text { Between } \\
\text { Groups }\end{array}$} & (Combined) & 1,011 & ,329 & ,652 \\
\hline & & Linearity &, 525 & ,153 & 631 \\
\hline & & Deviation from Linearity & 1,233 & ,387 & ,709 \\
\hline & \multicolumn{2}{|c|}{ Within Groups } & 1,252 & & \\
\hline & \multicolumn{2}{|c|}{ Total } & & & \\
\hline
\end{tabular}

Source: Secondary Data, 2021

Based on the significance value (sig), from the table above, the Deviation from Linearity Sig value is 0.709 greater than 0.05 . So it can be concluded that there is a significant linear relationship between the $\mathrm{X}$ variable and the $\mathrm{Y}$ variable.

\section{Heteroscedasticity Test}

The heteroscedasticity test aims to test whether in the linear regression model there is an inequality of variance from the residuals of one observation to another observation. A good regression model is one with homoscedasticity or no heteroscedasticity.

Table 3. Heteroscedasticity Test

\section{Coefficients $^{\mathrm{a}}$}

\begin{tabular}{|c|c|c|c|c|c|c|}
\hline \multirow[b]{2}{*}{ Mod } & & \multicolumn{2}{|c|}{$\begin{array}{l}\text { Unstandardized } \\
\text { Coefficients }\end{array}$} & \multirow{2}{*}{$\begin{array}{c}\text { Standardized } \\
\text { Coefficients } \\
\text { Beta }\end{array}$} & \multirow[b]{2}{*}{$\mathrm{t}$} & \multirow[b]{2}{*}{ Sig. } \\
\hline & & $\mathrm{B}$ & Std. Error & & & \\
\hline \multirow[t]{5}{*}{1} & (Constant) & 6,500 & 16,500 & & ,394 &, 432 \\
\hline & Hope Family Program &,- 169 & ,047 & $-1,704$ & $-3,576$ & 065 \\
\hline & Food Packages & ,084 & ,070 & ,773 & 1,192 & ,216 \\
\hline & Cash Social Assistance & ,549 & ,581 & 1,224 & ,945 & 195 \\
\hline & Economic growth & ,001 & ,001 &, 837 & 1,047 & ,308 \\
\hline
\end{tabular}

Source: Secondary Data, 2021

Based on the results of heteroscedasticity testing, all variables in this study, both independent and dependent variables, had a significance value of $>0.05$. This means that you accept $\mathrm{H} 0$, that is, all variables in the study have the same variance (homocedasticity).

Of the four exogenous variables, there are four variables (Family Hope Program, Basic Food Packages, Cash Social Assistance and Economic Growth) that meet the requirements of normality and homoscedasticity. This means that the four exogenous variables can use the Pearson Product Moment correlation test to see their relationship to the number of poor people.

\section{Rank-Spearman Test}

There is a correlation test or relationship between the independent variable and the dependent variable used in this study, namely Spearman-rho.

Table 4. Rank-Spearman Test

\begin{tabular}{lll}
\hline Number of Poor Population (Y) & Spearman-rho & Sig (2- Tailed) \\
\hline Hope Family Program & $-0,653$ & 0,047 \\
\hline Food Packages & $-0,790$ & 0,032 \\
\hline Cash Social Assistance & 0,024 & 0,019 \\
\hline Economic growth & $-0,738$ & 0,042 \\
\hline
\end{tabular}


Source: Secondary Data, 2021

The results of the Spearman-rho correlation test between the variables of the Family Hope Program, Basic Food Packages, Cash Social Assistance with the variable Number of poor people show a significance value ( $p$-value) smaller than the real level (error tolerance) of 0.05 . This means that rejecting $\mathrm{H} 0$, there is a significant relationship between the Family Hope Program, Basic Food Packages, Cash Social Assistance and the number of poor people.

The correlation test between the Family Hope Program, Basic Food Packages, Cash Social Assistance and the number of poor people is indicated by the significance value. It was found that the significance value was $l>0.05$. This means that you accept $\mathrm{H} 0$, that is, there is no significant relationship between the Family Hope Program, Basic Food Packages, Cash Social Assistance and the number of poor people. This result is supported by previous research which proves that there is no statistically significant relationship between economic growth and poverty (Sudarlan, 2015).

Based on the results of the correlation test, it has a relationship with the number of poor people who have different levels of closeness and influence. Therefore, it will be discussed how big the level of relationship and influence between these variables on the number of poor people.

\section{Analysis of the Relationship of the Hope Family Program, Food Packages, Cash Social Assistance to the Number of Poor People}

Based on the results of the correlation test between the social assistance program and the number of poor people, it shows a negative effect. This means that the higher the Bangka Belitung Islands Provincial government budget for social assistance will have an impact on reducing the number of poor people.

However, the relationship between each of these aid programs varies with the number of poor people. The Harpan Family Program has a very strong negative relationship with the number of poor people in Bangka Belitung. This is indicated by the value of the Spearman-rho correlation coefficient of -0.653 . This means that the family of hope program is able to significantly influence the number of poor people in Bangka Belitung. This is inseparable from the high amount of budget issued by the government for the family of hope program.

\section{Analysis of the Relationship between Eco- nomic Growth and the Number of Poor Pop- ulation}

The coefficient value of the Pearson Product Moment correlation test is 0.042. However, statistically, the positive value indicates that there is a positive and quite strong relationship between the level of economic growth and the number of poor people. This means that the higher Indonesia's economic growth rate will encourage an increase in the number of poor people. The insignificant relationship and influence of economic growth on the number of poor people is caused by the rate of increase in economic growth used in this study, namely from 2015 to 2020, which shows a trend of economic slowdown. Economic growth in the second quarter of 2020 experienced a fairly deep contraction of $-4.95 \%$. This is due to the Covid19 pandemic.

\section{Conclusion}

Based on the results of the study, it can be concluded that (1) there is a very strong relationship between social assistance programs, family programs of hope, basic food packages and cash social assistance to the number of poor people. The family of hope program has a strong relationship with the number of poor people. Another variable that is statistically proven to have a relationship with the number of poor people is government debt, (2) Statistically there is a negative influence between social assistance programs on the number of poor people.

\section{Acknowledgment}

This research is a funding grant from the University of Bangka Belitung so we thank the Institute for Research and Community Service (LPPM) of the University of Bangka Belitung and we also thank the Central Bureau of Statistics of Bangka Belitung Regency and the Government of Bangka Belitung Regency, Bangka Belitung Islands Province. 


\section{References}

\section{Article in a Journal:}

Economic Assessment of Health Care: Theory and Practice. J. Richardson ... First published: January 1991 https://doi.org/10.1111/i.14678462.1991.tb00378.x.

Septiadi D, H. d. (2016). Dampak Kebijakan Harga Beras dan Luas Areal Irigasi terhadap Pengentasan Kemiskinandi Indonesia. Jurnal Agribisnis Indonesia, Volume 4 Nomor 2.

\section{Chapter in a Book:}

Arsyad, Lincolin. 2010. Ekonomi Pembangunan, Edisi kelima. Yogyakarta: UPP. STIM YKPM

Muta'ali, Lutfi, 2015. Teknik Analisis Regional Untuk. Perencanaan Wilayah Tata Ruang dan Lingkungan. Yogyakarta: Badan Penerbit Fakultas Geografi.
Sukirno, Sadono.2010.Makroekonomi, Teori Pengantar.Edisi Ketiga. Jakarta:PT Rajagrafindo Persada.Tarigan, Robinson. 2007.Ekonomi Regional Teori dan Aplikasi(Edisi Revisi).Jakarta:PT BumiAksara.

Tulus TH Tambunan. (2001). Perekonomian Indonesia: Teori dan Temuan. Empiris. Jakarta: Ghalia Indonesia.

\section{Link / URL:}

Kemenkeu, R. (2020). Profil Utang dan Penjaminan Pemerintah Pusat. www.djppr.kemenkeu.go.id

Badan Pusat Statistik (BPS). (2020). Produk Domestik Bruto Indonesia Menurut Pengeluaran 2013-2020. Diakses dari www.babel.bps.go.id. 